\title{
CUSTOMS ADMINISTRATION IN UKRAINE: PROBLEMS OF DEVELOPMENT
}

Modern national customs legislation is improved and develops following global trends and taking into account the fundamental international conventions in the area of customs regulation. The process became primitive after the ratification of Ukraine-European Union Association Agreement in 2014. Moreover, as out international partners say, a large number of issues which should be resolved after the signing the Agreement are still open. For example, in Ukraine, the institute of an authorized economic operator is not introduced, and risk management system doesn't work effectively. The problems are stated, taking into account the generalization of the practice of customs control, the introduction of new technologies and implementation in the national legislation of dictates of international acts. The paper analyses the factors and conditions that negatively affect law enforcement activities of customs authorities of Ukraine and blunt its effectiveness.

In particular, it is proved that the development of international economic activity in Ukraine, its intensity, qualitative and quantitative composition of parties of the international economic activity fully depends on priorities of customs administration which are defined by the executive board of the national customs administration. Improvement of the mechanism of customs administration should envisage the shift of priority of management functions - transition from administrative to economic methods of management activity. National customs administration should use more comprehensively such methods as post-audit, remote monitoring of the subjects of international economic activity, provision of some benefits and preferences to unreliable undertakings etc., and facilitation of the procedure of customs control and registration, and suchlike.

The author believes that the very achievement of an adequate balance between the volume and effectiveness of customs procedures and guarantee of the implementation of economic rights of the actors of international economic activity will contribute to the level increase of market competition in the state and make the integration of the national economy in the world economy possible.

Key words: customs administration, participant of foreign trade activities, violation of rights, business community, risk, efficiency.

JEL Classification: F53.

\section{Oleksandr POLISHCHUK,} University of Customs and Finance, Ukraine policyk1@mail.ru

\section{Introduction}

The development and improvement of customs administration in Ukraine is conducted in accordance with the provisions of international law, the fundamental of which are the Kyoto Convention and the WTO Framework standards.

Level and quality of implementation of international customs law in Ukraine significantly affects the development of its international trade. The study and development of modern customs technologies, the use of electronic software products are made to reduce the time of customs control, as well as to improve the efficiency of its results. 
After the entry into force of the new edition of the Customs code of Ukraine since mid-2012, progress was achieved thanks to introduction and implementation of modern technologies of customs control, the creation of institutions such as the authorized economic operator (hereinafter-AEO), risk management system (hereinafter - RMS), etc.

The process of transformation of the customs system of Ukraine to the standards of modern customs administration is faced with the influence of negative factors that arose in the previous period of development. They not only slow down the rates of introduction of positive changes, but also conduce to adaptation of the old problems to new working conditions of customs authorities of Ukraine.

\section{Theoretical basis and legislation}

The sources containing information on problematic issues in the work of the customs authorities of Ukraine include:

- news and specialized sites "Internet" (for example, "www. ord.com.ua");

- materials of meetings, seminars, where the issues of customs regulation are discussed;

- analytical information of the State fiscal service of Ukraine;

- law enforcement and judicial information.

Research of problems of application by customs authorities of the customs legislation, interaction with participants of foreign economic activity (further - participants of foreign economic activity), work of RMS and its efficiency is complicated for the objective reasons. There are legally established restrictions on the dissemination of official customs information, as well as obtaining it by third parties.

The purpose of the study - based on the analysis of problems in the work of the customs authorities of Ukraine to determine the ways to solve them.

To date, customs is an important tool to ensure the public interest, namely:

- protection of the national market;

- security and welfare of the population;

- ensuring revenues to the budget.

An important basis for the development of customs are the principles of its implementation, which reflect the system of fundamental, important provisions and values describing the interaction between entities that carry out foreign economic activity (FEA).

In accordance with the legislation, the state customs affair is carried out on the basis of the following principles:

1) exclusive jurisdiction of Ukraine on its customs territory;

2) exclusive powers of the bodies of income and fees of Ukraine in the framework of the state customs Affairs;

(3) rule of law;

(4) legality;

5) observance of customs relations balance of interests of the state, individuals and legal entities;

6) inadmissibility of double taxation;

7) unity of customs regimes;

8) transparency, publicity [1].

The course taken by Ukraine to integrate the economy to the European community requires further harmonization of national legislation with international standards, consolidation of generally accepted standards in international practice. Modern legislation in the field of foreign 
trade of Ukraine is in the process of continuous improvement thanks to the reform processes that has been led in the state. But there are obstacles on the way of reformation caused objective and subjective factors.

The current practice of application of customs legislation allows cases of non-compliance of customs authorities of Ukraine with the rights of traders.

Such actions can justify the necessity of fulfilling the internal tasks set before the customs authorities (for example, achieving indicators for collecting customs payments by increasing the customs value of goods).Customs officials may violate the rights of traders also because of personal or other interest(execution of management instructions, under the influence of third parties,for other reasons).

The stereotype of behavior providing restriction or violation of the rights of participants of foreign economic activity for the purpose of achievement or performance of the tasks set by higher bodies or officials practically never leads to occurrence of negative legal consequences for violators - attraction them to the certain type of responsibility (disciplinary, civil, criminal) by the legislation.

Impunity entails the violation of the rights of participants of foreign trade activities by officials of customs bodies as well as corruptive practices.

Violation of the rights of foreign trade participants, as the practice of customs control, may occur due to the quality of training of customs authorities to solve their tasks. The mechanisms of modern customs administration suggest a change in the functional orientation and level of training of customs officials - today there is a need for specialists inclined to analytical work, who in addition to knowledge of customs legislation are able to study and analyze the processes and changes taking place in international trade, as well as to assess their impact on the technology of customs control [2]. The lack of specialists of appropriate qualification leads to errors in the application of the provisions of customs legislation and the implementation of norm-setting, the functioning of RMS.

For foreign trade participants, the reasons for the restriction (violation) of their rights by customs officials are not of fundamental importance, since in any case they bear negative consequences. Challenging the actions and decisions of officials may entail additional commercial risks associated with further "corporate revenge" on the part of customs authorities. Therefore, many traders perceive illegal actions of customs officials as a negative factor, which can not be influenced.

Interaction of customs authorities with participants of foreign economic activity.

Customs administration at the present stage involves the establishment of interaction of customs authorities with the business community, which is based on mutual interests, variable forms of cooperation, the desire for trusting relationships [3].

Interaction of customs authorities with foreign trade participants can be formalized, as well as be informal.

The formal interaction should include:

- interaction in accordance with the provisions of existing regulations during the implementation of customs control;

- establishment of formal cooperation in various forms.

The WTO Framework of standards States that customs administrations should establish partnerships with representatives of the business community in order to involve them in the work to ensure the safe and secure functioning of the international supply chain.

The basis of the partnership of customs authorities with representatives of the business community are: 
1) mutual interests;

2) the degree of trust in each other.

Under mutual interests should be understood, on the one hand, the involvement of the customs authorities of bona fide participants of foreign trade activities to assist in the task of minimization of customs risks, on the other hand, the desire of traders to minimize their commercial risks associated with the carrying out of customs control, sovershennoletnih other operations [4].

Trust in each other is the understanding of foreign trade participants of the legality and validity of the actions of customs authorities and confidence in their impartiality, and from the customs authorities - the establishment of formal cooperation with bona fide foreign trade participants.

The mechanism of partnership is the cooperation of the customs authorities of Ukraine with the AEO. The Institute of AEO in Ukraine is at the stage of formation, so the partnership between the customs authorities and AEO currently do not have the same rezultates as in many other countries where they are long-term and mutually beneficial [5].

Development of the Institute of AEO in Ukraine interferes with the formal cooperation between representatives of individual traders and customs officials.

Lack of formalized coordination between the customs authorities with participants of foreign economic activity flechette an increase in informal contacts. They in turn entail corruption risks, and as their consequence -potential risks of violation of the customs legislation [6]. Foreign trade participants who do not have or have not been able to establish informal contacts with customs authorities, but are aware of their presence in other foreign trade participants, begin to lose confidence in the actions of customs authorities.Such foreign trade participants may attempt to establish informal contacts, or begin to conduct minimization of their commercial risks associated with customs control, using a variety of methods and schemes, including illegal ones.

The lack of a sufficient number of AEO in the structure of foreign trade participants of Ukraine, who are interested in cooperation with the customs authorities in order to promote compliance with customs legislation by all foreign trade participants, is one of the problems of the development of the customs system of Ukraine.

Efficiency of RMS operation.

The customs authorities of Ukraine use one of the best national program complexes "Inspector 2006"in their activities for customs control and customs clearance. Its actual and potential capabilities allow to solve any problems on application of RMS [7].

The main objectives of the use of RMS by customs authorities are:

- ensuring the effectiveness of customs control and the use of customs resources;

- creation of conditions for speeding up and simplifying the movement of goods across the customs border.

The task of the customs system is to maintain a balance in the implementation of these tasks.

If one of the purposes of using RMS is given a clear preference (for example, the effectiveness of customs control), the RMS can be transformed from a risk management tool into a business management tool. Through the use of RMS, it is possible to show the impact on the redistribution of cargo flows, changes in the characteristics of goods (cost, etc.) essential for the results of customs control, etc. SUR allows you to restrict the holding of foreign economic activities of individual traders and/or predstavleniyah, which may not have an objective need and/or justification.

Such application of RMS is typical for the customs system of Ukraine at the present time. 
For traders SUR is a non-personalized system of decision-making associated with potential дополнительнымикоммерческимирисками.In the process of using RMS, conflict situations may arise, their solution depends on the level of interaction between customs authorities and foreign trade participants.Lack of proper interaction means for traders that commercial risk factors are not specific cases of application of RMS, and the activity of customs authorities as a whole.

Decisions generated by RMS are challenged by traders in court, which means the lack of business confidence in the customs authorities. Judicial bodies in the process of consideration of complaints of foreign trade participants give a legal assessment of the work of customs authorities, and indirectly assess the effectiveness of the use of RMS.

Currently, the effectiveness of the use of RMS is assessed by the following entities:

- customs administration (departmental assessment);

- foreign trade participants (external evaluation by stakeholders);

- judicial authorities (external evaluation by independent persons, as required).

For the customs authorities of Ukraine performance indicators of RMS is the number of identified risks and the availability of high results achieved from the application of measures to minimize them, as well as an increase in the percentage of bona fide traders and the volume of their foreign economic operations.

These performance indicators of RMS are interdependent and interdependent. Improving the effectiveness of the application of measures to minimize risks objectively should help reduce the number of unscrupulous traders.

But all these indicators are operated by the person interested in their positive dynamics the State Fiscal Service of Ukraine.

Departmental assessment of the results of the RMS does not allow to objectively determine the status of compliance with customs legislation by traders, to establish what influence of RMS (negative or positive) has on the implementation of foreign trade, as well as to evaluate the activities of customs authorities on the effectiveness of the RMS. The evaluation of the work of the RMS should be carried out with the participation of all stakeholders. In addition to the customs authorities, these include foreign trade participants, as well as other state bodies that exercise departmental control over the state of domestic processes that depend to a greater or lesser extent on foreign economic activity.

Only on the basis of comparison and analysis of indicators of activity of customs bodies on the application of SUR with the results and analysis of the activities of other state bodies and associations, and other associations of participants of foreign trade, the independent expert organizations (including international), which reflect the influence of the state in the sphere of foreign economic activity on the processes under their competence, it is possible to evaluate the efficiency of the SUR and the customs system as a whole.

The index of Ukraine in the doing business rating (international trade) is one of such independent assessments of the effectiveness of the customs administration of Ukraine.

The solution of topical issues of customs administration is associated with the presence of a modern and effective system of customs management. Many problems of the customs system of Ukraine are not solved or are not solved quickly and effectively due to management errors that have arisen as a result of the merger of the customs and tax authorities of Ukraine into a single Agency - the SFS of Ukraine.

\section{Conclusions}

Based on the above, the main aspects should be highlighted:

- the development of the customs system of Ukraine is aimed at the achievement of international standards of customs administration, the basis of which are the provisions of the Kyoto Convention and the WTO Framework of standards; 
- the introduction of the provisions of international regulations in the national customs legislation, as well as the use of modern technologies of customs control is not a guarantee of achieving improvements in the field of foreign trade and improving the efficiency of customs control;

- the presence of unsolved problems in the previous periods of development of the customs system of Ukraine, leads to the fact that the introduction of modern forms and methods of customs control (for example, the use of RMS) has both positive and negative impact on the rule of law and the intensity of foreign trade;

- the modern system of customs administration should be based on the formalized interaction of customs authorities with foreign trade participants;

- variable formalization of interaction between foreign trade participants and customs authorities helps to minimize commercial and customs risks, allows to participate in the assessment of the effectiveness of the work of the representative of the business community, and also helps to establish the process of discussion and resolution of issues of law enforcement of customs legislation;

- the development of foreign economic activity in Ukraine, its intensity, qualitative and quantitative composition of foreign trade participants largely depends on the definition of the leadership of the SFS of Ukraine customs administration priorities that will help to establish and maintain a balance between ensuring the effectiveness of customs control and assistance to foreign trade participants in foreign economic operations.

At the same time, taking into account the "package of reforms" approved by the President of Ukraine, in particular on decentralization Vlast, and the trend of global integration, today Ukraine faces the task of improving its state policy in the field of foreign trade. In fact, it is necessary to change the priorities of management functions - the transition from purely administrative management to balanced regulation. Among the methods of foreign trade regulation (legal, administrative, economic and socio-psychological), the international community provides an obvious priority to legal methods as the basis for the formation and functioning of other mechanisms of public management of such a system of management. Taking this into account, we believe that the state policy of Ukraine in the field of foreign trade should be aimed at improving the system of methods of its implementation by adjusting the domestic legislative framework, expanding Ukraine's participation in international relations, as well as the introduction of remote control in the field of foreign trade and remote customs surveillance.

\section{References:}

1. Customs code of Ukraine: practical projects: educational collaborator / ed. count.: A. Voicemal, And. Vashuk, Kresowaty A. O. Omelchuk, P. Pasko TA I n. Ternopil: TNEU, 2016. 516 p.

2. Miten right: ptuc. / A. Kresowaty, S. Geraki, O. Dem, Anouk the IR.; edited by A. Crisostomo. Ternopil: HCV "Ekon. Dumka TNEU”, 2014. Five hundred forty

3. Yakovlev I. P. Forms and methods of public administration in the State customs dis. kand. the faculty of law. Sciences: special. 12.00.07. Odes, 2016. 224 p.

4. Kahovec O. O Kahovec Y. O. Problematic issues of the institutional in Ukraine. Legal research e-journal. 2017. No. 2. P. 77-79. URL: http://www.lsej.org.ua/2_2017/24.pdf.

5. Gumenyuk O. G. On the basic principles of customs regulation of foreign economic activity. Scientific Bulletin of Kherson state University. Series "Economic Sciences". 2016. Issue. 16. Part 4. P. 113-116.

6. Results of the Department of tax and customs expertise of DFS in 2017 [Electronic resource] // State fiscal service of Ukraine. - 2018. URL: http://sfs.gov.ua/pro-sfs-ukraini/struktura-/spetsializovan-departament-taorg/spetsializovana-laboratoriya/diyalnist/rezultati-roboti/print-322556.html.

7. Revak, N.. Ways to improve the effectiveness of MH / N.. Rivak // Scientific Herald nltu Ukrainy : ZB. sciences'.-tech. labours'. - Lviv: Runleonrun. - 2017. - Issue. 21.3. - P. 224-232. 


\title{
МИТНЕ АДМІНІСТРУВАННЯ В УКРАЇНІ: ПРОБЛЕМИ РОЗВИТКУ
}

\author{
Олександр ПОЛІщУК, \\ Університет митної справи та фінансів, Украӥна \\ policyk1@mail.ru
}

Сучасне наиіональне митне законодавство удосконалюється та розвивається у відповідності до міжнародних тенедениій та з урахуванням основних міжнародних конвениій в сфері митного регулювання. Особливо примітним став цей процес після ратифікації Угоди про асоціаџію між Україною та ЄС у 2014 р.

Разом з тим, як зазначають наші міжнародні партнери, значна кількість питань, які повинні були бути розв'язані після підписання Угоди залишаються невиріменими. Так, наприклад, в Україні не запроваджено інститут уповноваженого економічного оператора, не ефективно працює система управління ризиками тощо.

У пропонованій статті досліджуються основні проблеми та окреслюються шляхи розвитку та удосконалення механізму митного адміністрування в Україні. Проблеми викладені з урахуванням узагальнення практики здійснення митного контролю, з урахуванням запровадження нових технологій та імплементації в національне законодавство приписів міжнародних актів. Здійснено аналіз факторів та умов, щуо негативно впливають на правозастосовну діяльність митних органів України, знижують ї̈ ефективність.

Зокрема, доведено, щуо розвиток зовнішньоекономічної діяльності в Україні, їі інтенсивність, якісний та кількісний склад суб'єктів зовнішньоекономічної діяльності повною мірою залежить від пріоритетних напрямків митного адміністрування, які будуть визначені керівництвом національної митної адміністрації. Удосконалення механізму митного адміністрування повинно передбачати зміну пріоритету управлінських функиій - перехід від адміністративних до економічних методів управлінської діяльності. Національна митна адміністрація повинна більш широко використовувати такі методи як пост-аудит, дистанційний контроль за суб'єктами зовнішньоекономічної діяльності, надання певних пільг та преференцій сумлінним суб'єктам господарювання тощуо, спрощзення щзодо них процуедур митного контролю та оформлення тощзо. Вважаємо, що тільки досягнення розумного балансу між обсягом й ефективністю митних процедур та забезпеченням реалізації економічних прав суб' єктів зовнішньоекономічної діяльності сприятиме підвищенню рівня ринкової конкурениї в державі, дозволить ивидше інтегрувати національну економіку в світове господарство.

Ключові слова: митне адміністрування, учасник ЗЕД, порушення прав, бізнесспівтовариство, ризики, ефективність. 